\title{
Lectin binding to serous ovarian tumours
}

\author{
K O SÖDERSTRÖM
}

From the Department of Pathology, University of Turku, Finland

SUMMARY Sections of normal ovarian surface epithelium, benign serous cystadenomas, borderline serous cystadenomas and serous cyst-adenocarcinomas were stained with a pattern of lectins (Con A, WGA, SBA, DBA, UEA I, PNA and RCA I) to determine the different glycoproteins and their cellular changes. The epithelial cells stained with Con A, WGA, UEA I and RCA, although the intensity of the staining was generally higher in the malignant tumours. PNA stained only the malignant cells of the cystadenocarcinoma and DBA only the benign epithelial cells. These findings show that ovarian epithelial cells contain different glycoconjugates and that malignant transformation is accompanied by changes in the composition of these glycoconjugates.

Lectins are proteins derived from plants, animals, or micro-organisms that bind to specific terminal sugar residues in carbohydrates. The binding is affected by the structure of the carbohydrate chain so that even small changes within the carbohydrate molecule can cause changes in the binding of lectins. ${ }^{1}$ Lectins with the same terminal sugar specificities, therefore, do not necessarily show the same binding patterns. Lectin histochemistry can thus detect small changes in the composition of glycoproteins and it has been used in the study of normal cellular differentiation ${ }^{2-5}$ and also in the study of malignant cells..$^{6-8}$

The epithelial tumours of the ovary form a heterogeneous group, derived from the surface epithelium of the ovary. ${ }^{9}$ Periodic acid Shiff staining has shown that both the surface epithelium of the ovary, ${ }^{10}$ as well as ovarian serous tumour cells, ${ }^{11-12}$ contain different glycoproteins. To study in more detail the glycoproteins and their changes in these cells, the lectin staining patterns of ovarian surface epithelium as well as benign, borderline, and malignant serous ovarian tumors were studied.

\section{Material and methods}

Tissue specimens obtained during the removal of ovarian tumours were fixed in $10 \%$ neutral buffered formalin, dehydrated, embedded in paraffin, sectioned to $5 \mu \mathrm{m}$ thickness, and stained with the van Gieson stain. The following specimens were studied by lectin histochemistry: 10 normal ovaries from patients aged 42-50 years); 10 serous cystadenomas (from patients aged between $40-58$ years); 10 serous borderline cystadenomas (from patients aged between 42-60

Accepted for publication 20 October 1987 years); 10 serous well differentiated cystadenocarcinomas (from patients aged between 52-66 years).

The following fluorescein isothiocyanate conjugated lectins (Vector Laboratories, Burlingame, California, USA) were studied: concanavalin A (Con A), Triticum vulgaris (WGA), Glycine maximum (SBA). Dolichos biflorus (DBA), Ulex europaeus (UEA I), Arachis hypogaea (PNA), and Ricinus communis (RCA I). The inhibitory sugars L-fucose for UEA I, $\mathrm{N}$-acetyl-D-glucosamine for WGA, and $\mathrm{N}$-acetyl-Dgalactosamine for DBA and PNA were obtained from Calbiochem-Behring, San Diego, USA. D-mannose inhibitory sugar of Con A and D-galactose inhibitory sugar of RCA I and SBA were obtained from Sigma Chemical, St Louis, Missouri, USA. The properties of the lectins are summarised in table 1.

Slides of paraffin embedded tissue sections were deparaffinised with xylol, processed through a descending series of ethanols, and $100 \mu \mathrm{l}$ of the lectins at a

Table 1 Lectins used in this study

\begin{tabular}{lll}
\hline Lectin origin & $\begin{array}{l}\text { Major sugar } \\
\text { specificities }\end{array}$ & $\begin{array}{l}\text { Binding } \\
\text { inhibitor }\end{array}$ \\
\hline $\begin{array}{l}\text { Canavalia ensiformis } \\
\text { (jackbean)(Con A) }\end{array}$ & Man; Glc & Man \\
$\begin{array}{c}\text { Tritium vulgaris } \\
\text { (wheat germ) (WGA) }\end{array}$ & NeuNac; GlcNac & GlcNac \\
$\begin{array}{c}\text { Glycine maximum } \\
\text { (soybean)(SBA) }\end{array}$ & GalNac; Gal & GalNac \\
$\begin{array}{c}\text { Dolichos biflorus } \\
\text { (horse gram)(DBA) }\end{array}$ & GalNac & GalNac \\
$\begin{array}{c}\text { Ulex europaeus } \\
\text { (Gorse)(UEA I) }\end{array}$ & $\alpha$-L-Fuc & $\alpha$-L-Fuc \\
$\begin{array}{c}\text { Arachis hypogaea } \\
\text { (peanut)(PNA) }\end{array}$ & Gal-(1-3)-GalNac & GalNac \\
$\begin{array}{c}\text { Ricinus communis } \\
\text { (castor bean)(RCA I) }\end{array}$ & Gal & Gal \\
\hline
\end{tabular}

Man: Mannose, Glc: Glucose, GlcNac: $\mathbf{N}$-acetylglucosamine, NeuNac: $\mathrm{N}$-acetyl-neuraminicacid (sialic acid), Gal: galactose, $\beta$-LFuc: $\beta$-L-Fucose, GalNac: $N$-acetylgalactoseamine. All sugars are $\beta$ D-configuration, unless otherwise stated. 
concentration of $0.1 \mathrm{mg} / \mathrm{ml}$ in phosphate buffered saline (PBS) at $\mathrm{pH} 7.4$ was applied. The sections were incubated in a humidity chamber for two hours at room temperature, washed three times in PBS (once in distilled water), dried and mounted with Fluormount. The specificity of the staining was tested by preincubating the lectins in a solution of the appropriate inhibitory sugar at a concentration of $0 \cdot 1 \mathrm{M}$, except for D-mannose for which the concentration was $0.3 \mathrm{M}$. The tissue sections were examined with a Leitz epifluorescence microscope equipped with the appropriate filter combination for fluorescein isothiocynate.

\section{Results}

The different lectins stained the tissue components differently (table 2).

\section{OVARIAN SURFACE EPITHELIUM}

The ovaries are covered by a flat epithelium, one cell layer thick, derived from the embryonal coelomic epithelium (fig 1). The epithelium was stained with Con A (fig 2), WGA, UEA I (in seven of 10 cases), DBA (eight of 10 cases), and RCA I. Con A and WGA stained the whole cytoplasm of the epithelial cells, although the staining was more intense basally; UEA I, DBA, and RCA stained only the apical surface of the cells. SBA and PNA did not stain the epithelial cells.

\section{SEROUS CYSTADENOMA}

In ovarian benign serous cystadenomas the epithelium often forms extensive papillary structures but the epithelial cells are usually in one row with no nuclear atypia or mitosis (fig 3). Con A stained the epithelial cells throughout the cytoplasm but the apical surface was most clearly stained (fig 4). WGA also stained the epithelial cells clearly (fig 5), although cytoplasmic granules were also occasionally stained. In some cases the apical surface of the epithelial cells was faintly stained with DBA (five of 10 cases) and UEA I (four of 10 cases) (fig 6). RCA I stained also the apical surface of the epithelial cells but more intensively than DBA or UEA I. SBA or PNA did not stain the epithelial cells.

\section{Table 2 Lectin binding pattern of serous ovarian tumours}

\begin{tabular}{lllll}
\hline & $\begin{array}{l}\text { Surface } \\
\text { epithelium }\end{array}$ & $\begin{array}{l}\text { Serous } \\
\text { cystadenoma }\end{array}$ & $\begin{array}{l}\text { Serous border } \\
\text { line cystadenoma }\end{array}$ & $\begin{array}{l}\text { Serous cyst- } \\
\text { adenocarcinoma }\end{array}$ \\
\hline CON A + & + & + & ++ & ++ \\
WGA + & + & ++ & ++ \\
SBA & - & - & - & - \\
DBA & + & +- & +- & + \\
UEA I & +- & +- & +- & + \\
PNA & - & + & - & ++ \\
RCA & + & + & ++ & ++ \\
\hline
\end{tabular}

SEROUS BORDERLINE CYSTADENOMA

In borderline serous ovarian cystadenomas the epithelium is often stratified (fig 7) but neither mitoses nor nuclear atypia are found. The epithelial cells stained in much the same way as the serous cystadenomas. There was a quantitative difference in the staining so that the epithelial cells of the borderline tumours were generally more intensively stained with lectins than the cells of normal surface epithelium or benign serous cystadenoma. Con $\mathrm{A}$ showed an intense staining of the apical border of the epithelial cells (fig 8) as did WGA (fig 9). WGA also showed a granular staining of the cytoplasm in some of the epithelial cells. In some cases DBA (seven of 10 cases) and UEA I (five of 10 cases) also faintly stained the apical surface of the epithelial cells. RCA I showed a clear and intense staining of the apical surface of the epithelial cells. Only SBA and PNA did not show any staining of the epithelial cells.

\section{SEROUS CYSTADENOCARCINOMA}

In serous cystadenocarcinomas of the ovary the cells show nuclear atypia and hyperchromasia with a high incidence of mitoses (fig 10). Con A stained the epithelial cells, but in the malignant cells the staining was usually more uniformly distributed in the cytoplasm than in the benign cells (fig 11). WGA stained both the apical surface of the cells as well as the cystic structures (fig 12). UEA I stained the apical surface of the cells (fig 13). PNA stained the apical surface of the cells and especially the secretion within the lumen of the cystic structures (fig 14). RCA I also stained the apical surface of the epithelial cells (fig 15).

In the control experiments no staining could be seen when the lectins were incubated with the appropriate inhibitory sugars.

\section{Discussion}

The results of this study show that the normal surface epithelial cells as well as the different serous tumours are stained with several lectins: this indicates that different glycoconjugates are present in these cells. That this staining is specific is shown by the preincubation of the lectins with inhibitory sugars which completely abolished the lectin staining. There are qualitative as well as quantitative differences in the staining of the different epithelial cells. Most epithelial cells were stained with Con A, WGA, UEA I, and RCA I, although the intensity of the staining was greater in the malignant tumours. Therefore it seems that malignant transformation in serous ovarian epithelial cells is accompanied by changes in the glycoconjugates contained in the cells. This agrees with the findings of previous studies using conventional methods which have shown that the amount of mucin and sialic acid residues in serous ovarian tumours increases with increasing malignancy. ${ }^{12}$ It is probably not a general phenomenon in malignant transformation because in breast epithelium the better 

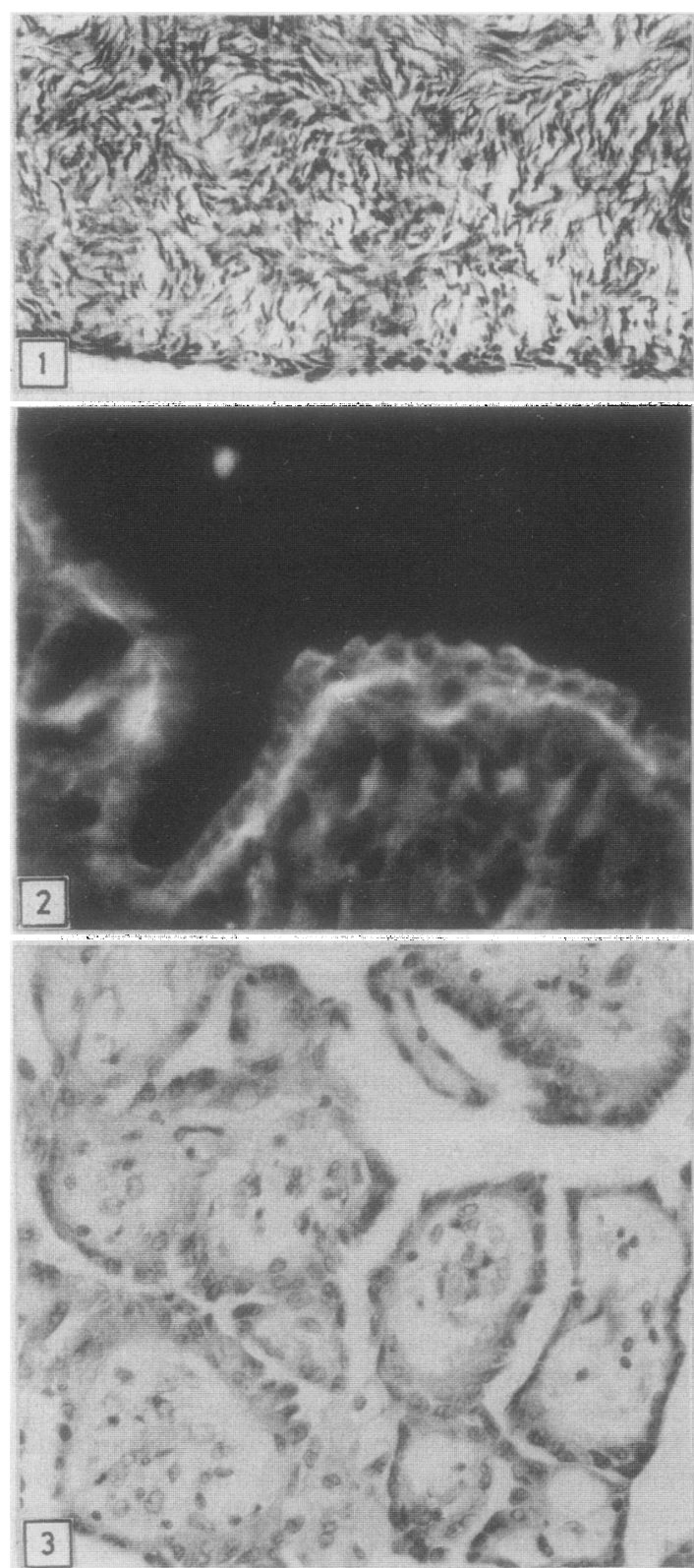
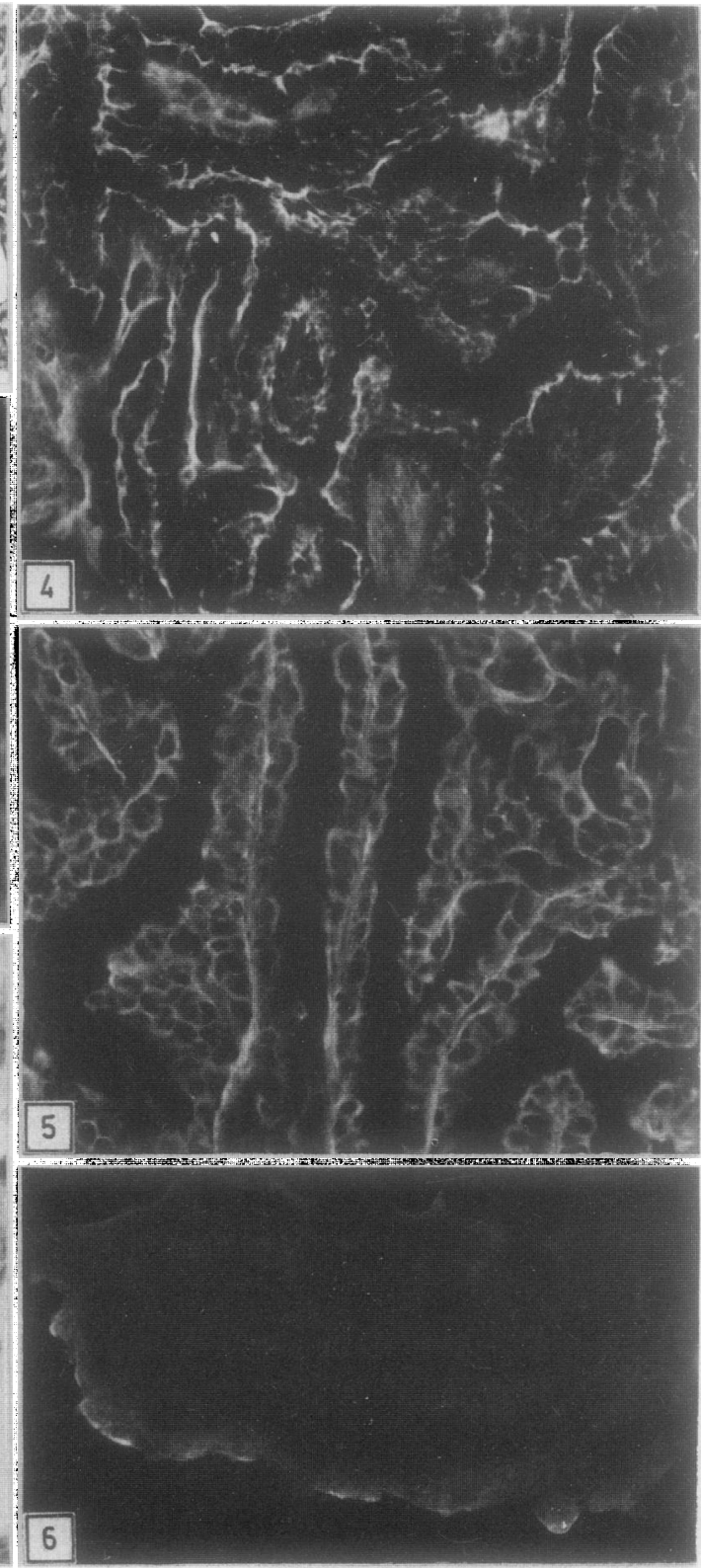

Fig 1 Light microscopic picture of normal ovarian surface epithelium. (Van Gieson staining.)

Fig 2 Con A staining of normal ovarian surface epithelium. Cytoplasm of epithelium cells is most intensively stained basally.

Fig 3 Light microscopic picture of epithelium of benign serous cystadenoma.

Fig 4 Con A staining of epithelial cells in benign serous ovarian cystadenoma. Most intense staining is seen apically.

Fig 5 WGA staining of epithelial cells in benign ovarian cystadenoma. Cells are also most intensively apically stained.

Fig 6 UEA I staining of epithelial cells in benign ovarian serous cystadenoma. Cells are slightly apically stained. 


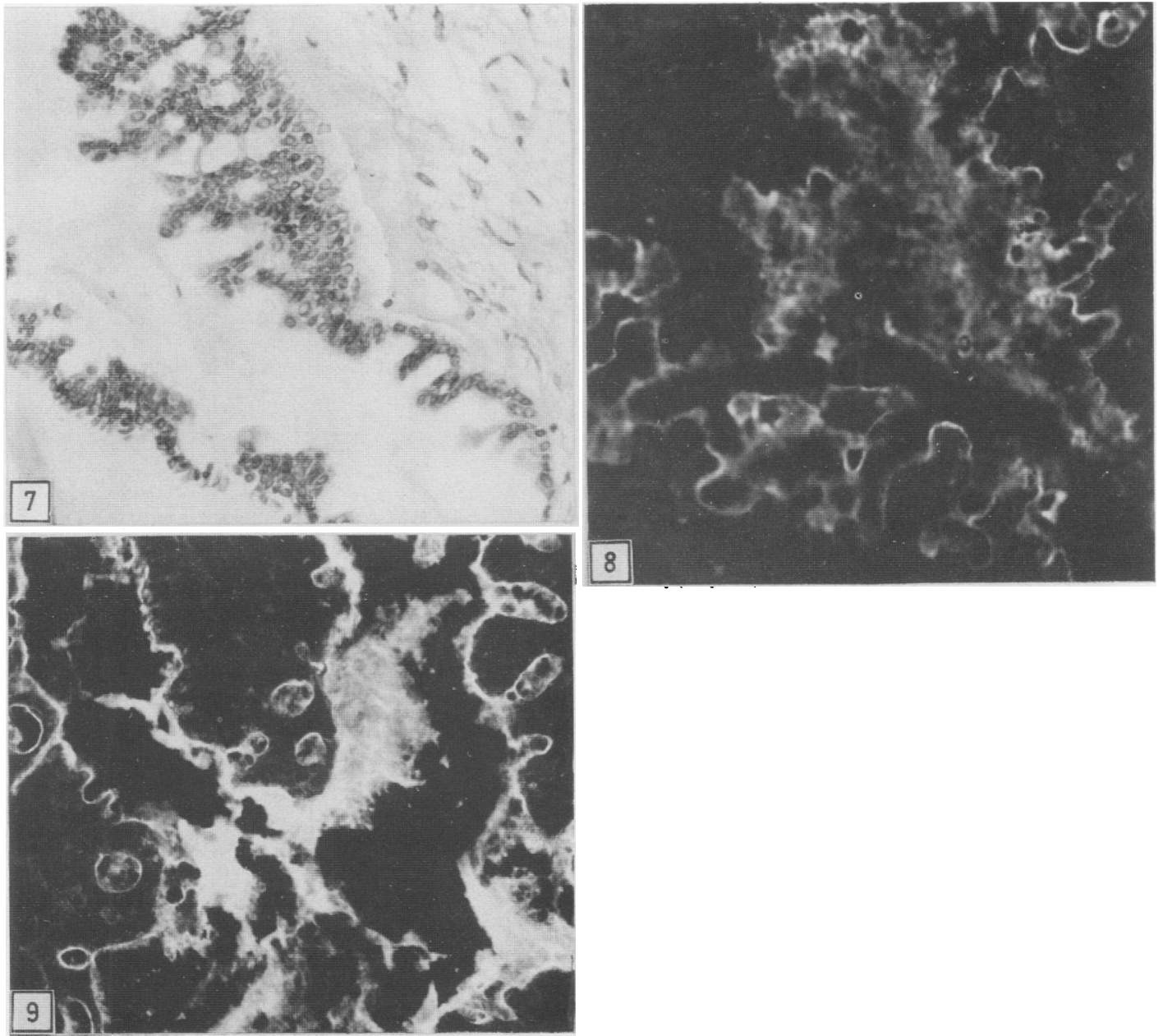

Fig 7 Light microscopic picture of epithelial cells from borderline serous ovarian cystadenoma. Epithelium is typically stratified with small papillary projections. (Van Gieson staining.)

Fig 8 Con A staining of epithelial cells from borderline serous ovarian cystadenoma. Cells are intensively apically stained.

Fig 9 WGA staining of epithelial cells from borderline serous ovarian cystadenoma. Cells are apically stained along brush border. Secretion within lumen of cyst-like structures is also stained.

differentiated cells are more intensively stained with PNA $^{6}$ than undifferentiated malignant cells.

All epithelial cell types in this study were stained by RCA I, indicating the presence of terminal galactose residues in the glycoconjugates. PNA did not stain the benign or borderline serous cystadenomas, but in the carcinoma cells there was a clear staining apically in most cells. This binding of PNA to carcinoma cells might be potentially useful in the differential diagnosis of ovarian carcinomas, although further studies are needed to establish its practical value. The binding of PNA is more restricted than that of RCA I and it binds to $\beta$-D-galactose-(1-3)- $\mathrm{N}$-acetylgalactosamine. ${ }^{13}$ The binding of PNA in the carcinoma cells therefore indicates that the malignant transformation of the epithelial cells might be accompanied by a formation of $\beta$-D-galactose-(1-3)- $\mathrm{N}$-acetylgalactosamine residues in the cytoplasm of these cells.

An interesting change in the lectin binding pattern was that DBA did not stain the malignant cells. The usefulness of this marker is diminished by the fact that it stained only part of the benign cells. Although the sugar binding specificities of SBA are similar to those of DBA, the epithelial cells were not stained. This 

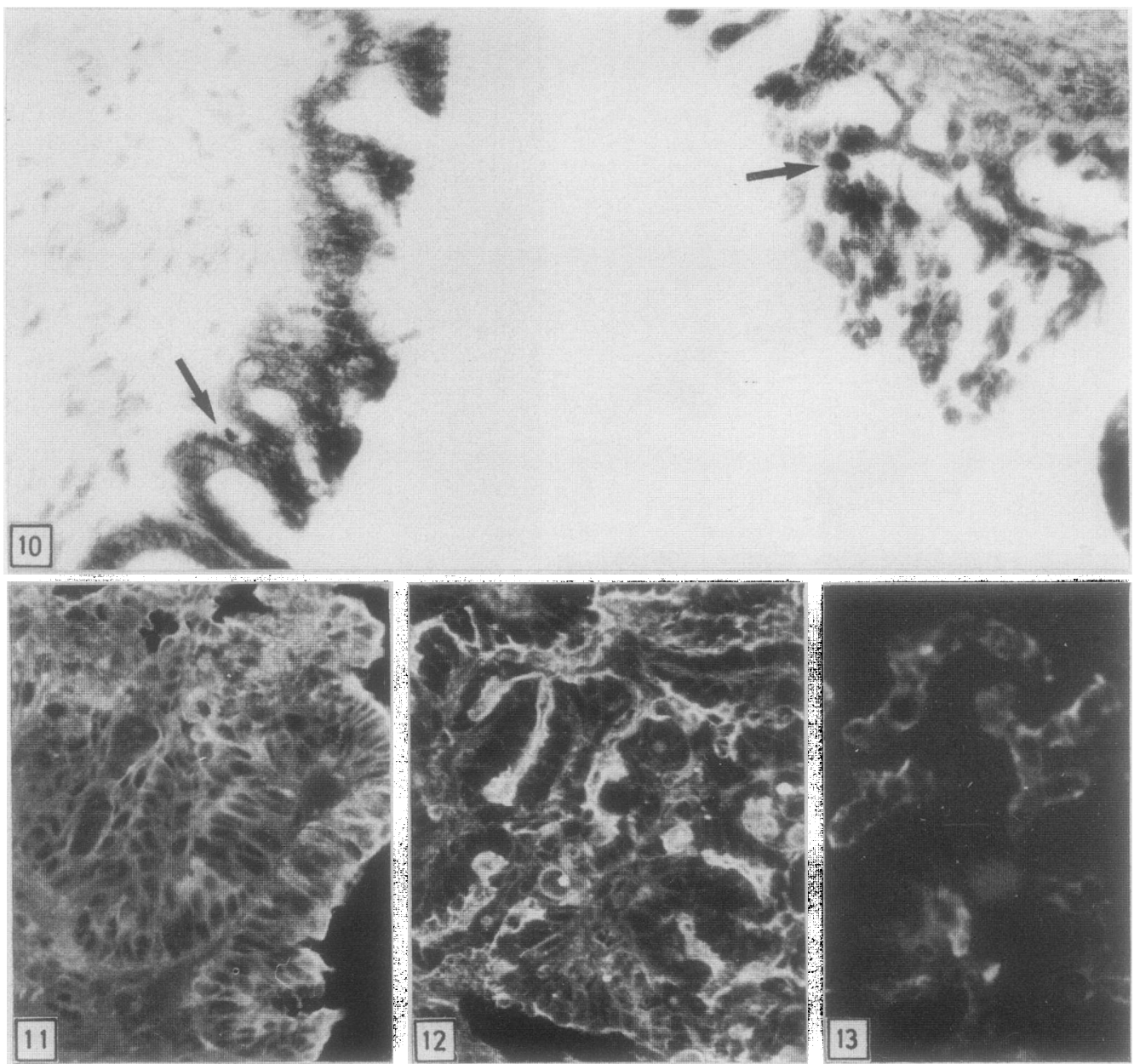

Fig 10 Light microscopic picture of epithelial cells from serous ovarian cystadenoma. Nucleus is hyperchromatic and some mitoses can be seen (arrows). This tumour was also clearly invasive.

Fig 11 Con A staining of epithelial cells from serous ovarian cystadenocarcinoma. Cytoplasm of cells is diffusely stained.

Fig 12 WGA staining of epithelial cells from serous ovarian cystadenocarcinoma. Cytoplasm of cells is apically stained. Content of cyst-like structures is also stained.

Fig 13 UEA I staining of epithelial cells from serous ovarian cystadenocarcinoma. Cells are apically stained.

could be explained if it is considered that the sugars within carbohydrate chains may also affect the binding of lectins: lectins with the same terminal sugar specificities do not always show the same binding pattern.'

The staining of the epithelial cells was heterogeneous, especially with DBA and UEA I. This shows that the cell population in the tumours is heterogeneous and that the glycoconjugates they contain may also vary.

WGA binds to sialic acid and to different oligomers of $\mathrm{N}$-acetylgalactosamine. ${ }^{13}$ In this study WGA stained the cytoplasm evenly in normal epithelial cells but mostly apically in the tumour cells. The intensity of the WGA staining was higher in borderline and malignant cells than in benign tumours or normal 

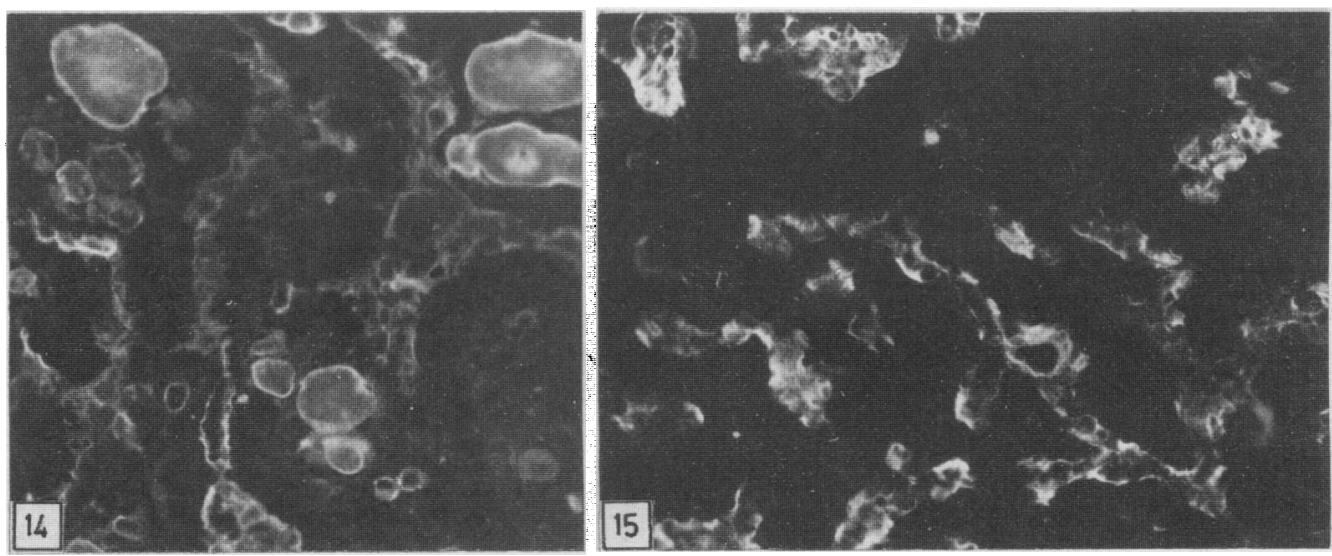

Fig 14 PNA staining of epithelial cells from serous ovarian cystadenocarcinoma. Epithelial cells are clearly apically stained in addition to content of cyst-like structures.

Fig 15 RCA I staining of epithelial cells from serous ovarian cystadenocarcinoma. Epithelial cells are apically stained.

epithelial cells. Sialic acid has been found apically in serous tumour cells of the ovary by high iron diamine staining at $\mathrm{pH} 2 \cdot 5$, combined with sialidase treatment,${ }^{14}$ and its amount seems to increase the higher the grade of tumour. Even in malignant serous tumours, however, the tumours containing sialic acid form only a small proportion of all the tumours, ${ }^{12}$ so that it seems that the increased WGA staining of the malignant cells is caused by $\mathrm{N}$-acetylgalactosamine residues rather than sialic acid.

Many of the lectins studied (WGA, PNA, DBA, UEA I and RCA I) bind mainly to the apical surface of the epithelial cells in the serous tumours. Previous more non-specific histochemical studies have shown sulphomucins, carboxymucins, and compounds with 1,2-hydroxyl groups in these sites. ${ }^{1}$ The Golgi complex, which has been reported to be stained with RCA and Con A, ${ }^{15}$ is often located in the apical part of the ovarian serous tumour cells, ${ }^{16}$ and this could explain the location of the staining.

The finding that normal surface ovarian epithelial cells contain several of the glycoconjugates also found in serous tumours supports the hypothesis that these cells are of the same origin - that is, they are derived from the coelomic epithelium.

\section{References}

1 Debray H, Decout D, Strecker G, Spik G, Montreul J. Specificity of twelve lectins towards oligosaccharides and glycopeptides related to N-glycosylproteins. Eur J Biochem 1981;117:41-55.

2 Söderström K-O, Malmi R, Karjalainen K. Binding of fluorescein isothiocyanate conjugated lectins to rat spermatogenic cells in tissue sections. Enhancement of lectin fluorescence obtained by fixation in Bouin's fluid. Histochem J 1984;80:475-9.

3 Hsu SM, Ree HJ. Histochemical studies on lectin binding in reactive lymphoid tissue. J Histochem Cytochem 1983;31: 538-46.

4 Brasitus TA, Goldfarb JP, Hsu KC, Tannenbaum M.
Characterization of rat colonic cell surface glycoconjugates by fluorescinated lectins I. Importance of fixation techniques. Histochem J 1982;76:197-209.

5 Holthöfer H, Miettinen A, Paasivuo R, et al. Cellular origin and differentiation of renal carcinomas. A fluorescence microscopic study with kidney-specific antibodies, antiintermediate filament antibodies and lectins. Lab Invest 1983;49:317-26.

6 Newman RA, Klein PJ, Rudland PS. Binding of peanut lectin to breast epithelium, human carcinomas, and a cultured rat mammary stem cell: Use of the lectin as a marker of mammary differentiation. JNCI 1979;63:1339-46.

7 Borisch B, Möller P, Harms D. Lektin ulex europaeus I als marker in der differentialdiagnose von gefässtumoren. Der Pathologe und Klinik 1983;4:244-51.

8 Malmi R, Söderström K-O. Distribution of glycoconjugates in normal human testis and in seminoma. In: Bög-Hansen TC, Breborowicz J, eds. Lectins, Biology, Biochemistry, Clinical biochemistry. Vol 4. Berlin: Walter de Gruyter \& Co, 1985: $145-54$.

9 Scully RE. Recent progress in ovarian cancer. Hum Pathol 1970;1:73-98.

10 Blaustein AU, Lee H. Surface cells of the ovary and pelvic peritoneum. A histochemical and ultrastructural comparison. Gynecol Oncol 1979;8:34-42.

11 Garcia-Bunuel R, Morris B. Histochemical observation on mucin in human ovarian neoplasms. Cancer 1964;17:1108-18.

12 Long ME, Sommers SG. Staging, grading and histochemistry of ovarian epithelial tumors. Clin Obstet Gynecol 1969;12:937-54.

13 Goldstein IJ, Hayes CE. The lectins: carbohydrate binding proteins of plants and animals. Advances in Carboxyhydrate Chemistry and Biochemistry 1978;35:127-340.

14 Klemi PJ, Nevalainen TJ. Ultrastructural and histochemical observations on serous ovarian cystadenomas. Acta Pathol Microbiol Scand (Sect A) 1978;84:303-12.

15 Pavelka M, Ellinger A. Localisation of binding sites for concanavalin A, Ricinus communis I and Helix pomatia lectin in the Golgi apparatus of rat small intestinal absorptive cells. $J$ Histochem Cytochem 1985;33:905-14.

16 Gondos B. Electron microscopic study of papillary serous tumours of the ovary. Cancer 1971;27:1455-64.

Requests for reprints to: Dr K-O Söderström, Department of Pathology, University of Turku, SF-20520 Turku, Finland. 